\title{
CARBETOCIN FOR PREVENTION OF POSTPARTUM HEMORRHAGE AFTER CESAREAN SECTION IN WOMEN WITH SEVERE PREECLAMPSIA IN COMPARISON TO OXYTOCIN
}

\author{
By
}

\author{
Ahmed Saad El-Dien, Mofeed Fawzy Mohammed and Ahmed \\ Mohammed El-Sadek \\ Department of Obstetrics and Gynecology, Faculty of Medicine, Al-Azhar University \\ *Corresponding Author: Ahmed Saad El-Dien, E-mail: drahmedsaad1989@yahoo.com
}

\begin{abstract}
Background: Postpartum hemorrhage (PPH) responsible for twenty to twenty five percent of maternal mortality. The major PPH mechanism is uterine atony, as it is active in fifty nine percent of pregnant. The use of uterotonics after birth is implicit in its avoidance.

Objective: To evaluate the effect of carbetocin in prevention of PPH after cesarean section in pregnant with severe preeclampsia (PE) in comparison to oxytocin.

Patients and Methods: This study involved 100 pregnant with severe PE with gestational age between 28 and 40 weeks. The patients were divided into two equal groups: group (A) received 100 microgram carbetocin dissolved in $5 \mathrm{ml}$ saline $0.9 \%$ direct I.V over 3 minutes, and group (B) received 40 i.u oxytocin I.V infusion.

Results: In carbetocin cases, 30 pregnant needed misoprostol to gain a good uterine contraction. In oxytocin cases, although a sustained infusion, ten pregnant had another oxytocin dose, and ten pregnant needed misoprostol dose. Also, prevalence of extra uterotonic doses in the carbetocin and oxytocin cases was $60 \%$ and $40 \%$, respectively $(\mathrm{P}=0.021)$. Oxytocin cases had significantly higher mean of period from oxytocin to misoprostol than carbetocin cases $(\mathrm{p}=0.001)$.

Conclusion: Carbetocin has the same efficacy and safety of oxytocin in PE. Since it's easy to administer, it needs a relatively small vehicle capability and has a long-lasting uterotonic efficacy.
\end{abstract}

Keywords: Postpartum Hemorrhage, Carbetocin, Oxytocin, Severe Preeclampsia.

\section{INTRODUCTION}

Preeclampsia (PE) is characterized by high blood pressure ( $\geq 140 / 90 \mathrm{mmHg})$, and proteinuria where urinary excretion occures $>300 \mathrm{mg}$ of protein in 24 hours, or $3 \mathrm{mg} / \mathrm{dL}$ of protein in 2 randomized urine samples after 20 weeks gestation. The prevalence of $\mathrm{PPH}$ is greater in $\mathrm{PE}$ patients than normal blood pressure pregnant (Fullerton et al., 2013).
Oxytocin has been the first uterotonic drug for PPH, and carbetocin was recently suggested. Carbetocin is a structural analogue of natural oxytocin, and has a long-acting uterotonic medication for the avoidance of PPH in C.S. Compared to existing uterotonic substances; carbetocin starts rapidly and lasts longer than sustained oxytocin infusion with a similar protection feature. Carbetocin is used as a single intravenous dose, a much smoother 
and less error-prone treatment than an oxytocin-dependent infusion (Elbohoty et al., 2016).

In this study, we aimed at determining carbetocin efficacy for prevention of PPH after C.S in pregnants with severe PE compared with oxytocin.

\section{PATIENTS AND METHODS}

This was a case control study which involved 100 pregnant with severe preeclampsia between 28 and 40 weeks gestation at AL-AZHAR University Hospitals (AL-Hussein and Bab ElSHa'riya), and Sohag Teaching Hospital during the period from October 2019 to October 2020.

After ethical committee and consents from the patients, all pregnant were divided into two groups:

- Group A received 100 microgram carbetocin dissolved in $5 \mathrm{ml}$ saline $0.9 \%$ direct I.V over 3 minutes.

- Group B received 40 i.u oxytocin I.V infusions.

\section{Inclusion criteria:}

- $\quad$ Systolic blood pressure $\geq 160$.

- $\quad$ Diastolic blood pressure $\geq 110$.

- Proteinuria +2 or more qualitative test.

- Clinical edema.

- Symptoms of CNS dysfunction as severe headache.

- Hepatic abnormality as high liver enzymes at least twice the normal, epigastric pain.

- Thrombocytopenia platelet count less than 100000ไmicro L.
- Progressive renal abnormality as high serum creatinine, oliguria, and anuria.

\section{Exclusion criteria:}

- Grand multipara more than five.

- Multiple fibroids.

- Anemia and malnutrition.

- $\mathrm{APH}$ as placenta previa.

- Uterine over distention as macrosomic baby.

- DIC.

All patients had been subjected to comprehensive history, general, local examination, ultrasound imaging and laboratory investigations (urine analysis, hemoglobin level, liver enzymes, creatinine and platelets count).

\section{Statistical analysis:}

Recorded data were analyzed using the statistical package for the social sciences, version 20.0 (SPSS Inc., Chicago, Illinois, USA). Quantitative data were expressed as mean \pm standard deviation (SD). Qualitative data were expressed as frequency and percentage. Independentsamples t-test of significance or Mann_Whitney U test was used when comparing between two means. Chi-square (X2) test of significance was used in order to compare proportions between two qualitative parameters. The confidence interval was set to $95 \%$ and the margin of error accepted was set to $5 \%$. The p-value was considered significant when $\mathrm{P}$-value $\leq 0.05$. 


\section{CARBETOCIN FOR PREVENTION OF POSTPARTUM HEMORRHAGE...}

\section{RESULTS}

Our results involved 100 pregnant. Their mean of age in carbetocin cases was 27.14, and in oxytocin cases was 26.99 years. No significant differences regarding age, gravidity, parity, abortion, gestational age, and severity of PE (Table 1).

Table (1): Maternal baseline characteristics

\begin{tabular}{|l|c|c|c|}
\hline Parameters & $\begin{array}{c}\text { Carbetocin group } \\
(\mathbf{n = 5 0})\end{array}$ & $\begin{array}{c}\text { Oxytocin group } \\
(\mathbf{n = ~ 5 0 )}\end{array}$ & P-value \\
\hline Age $_{\text {(years) }}$ & $27.14 \pm 4.9$ & $26.99 \pm 5.1$ & 0.881 \\
\hline Gravid & $1.8 \pm 1.1$ & $1.7 \pm 0.9$ & 0.542 \\
\hline Parity & $1.6 \pm 0.7$ & $1.4 \pm 0.7$ & 0.608 \\
\hline Abortion & $1.5 \pm 0.6$ & $1.09 \pm 0.5$ & 0.437 \\
\hline Gestational age $($ week) & $38.43 \pm 2.09$ & $38.85 \pm 1.09$ & 0.212 \\
\hline Severe hypertension, $\mathrm{n}(\%)$ & $37(74)$ & $39(78)$ & 0.640 \\
\hline Severe proteinuria, $\mathrm{n}(\%)$ & $10(20)$ & $11(22)$ & 0.806 \\
\hline Oliguria, (\%) & $1(2)$ & $1(2)$ & 1.00 \\
\hline HELLP syndrome, $\mathrm{n}(\%)$ & $10(20)$ & $11(22)$ & 0.806 \\
\hline $\begin{array}{l}\text { Eclampsia/neurologic } \\
\text { signs, } \mathrm{n}(\%)\end{array}$ & $35(70)$ & $36(72)$ & 0.826 \\
\hline
\end{tabular}

In carbetocin cases, 30 pregnant needed misoprostol to gain a good uterine contraction. In oxytocin cases, although a sustained infusion, ten pregnants had another oxytocin dose, and ten pregnants needed misoprostol dose. Also, prevalence of extra uterotonic doses in the carbetocin and oxytocin cases was $60 \%$ and $40 \%$, respectively $(\mathrm{P}=0.021)$. Oxytocin cases had significantly higher mean of period from oxytocin to misoprostol than carbetocin cases $(p=0.001)$. Average period of admission in intensive care unit (ICU) was significantly higher in oxytocin cases $(\mathrm{p}=0.001)$ (Table 2).

Table (2): Comparison between casess as regard to extra measures needed

\begin{tabular}{|l|c|c|c|}
\hline \multicolumn{1}{|c|}{ Groups } & $\begin{array}{c}\text { Carbetocin } \\
\text { group } \\
(\mathbf{n = 5 0})\end{array}$ & $\begin{array}{c}\text { Oxytocin } \\
\text { group } \\
(\mathbf{n = 5 0})\end{array}$ & P-value \\
\hline Need for extra uterotonics, $\mathrm{n}(\%)$ & $30(60 \%)$ & $20(40 \%)$ & $\mathbf{0 . 0 4 6}$ \\
\hline Time interval to extra uterotonics, minutes & $11 \pm 21.2$ & $80 \pm 10.4$ & $\mathbf{0 . 0 0 1}$ \\
\hline Need for compression balloon, $\mathrm{n}(\%)$ & $15(30 \%)$ & $1(2 \%)$ & $<\mathbf{0 . 0 0 1}$ \\
\hline Length of stay in intensive care unit, ${ }_{\text {days }}$ & $8 \pm 2.3$ & $12.2 \pm 4.2$ & $\mathbf{0 . 0 0 1}$ \\
\hline
\end{tabular}

The mean hemoglobin drop, blood loss, and massage times significantly raised in oxytocin cases in comparison to carbetocin cases $(\mathrm{P}<0.05)$, while the blood pressure and respiratory rate were comparable between the two groups $(\mathrm{P}>$ 0.05) (Table 3). 
Table (3): Comparison between casess as regard to hemodynamic changes

\begin{tabular}{|c|c|c|c|}
\hline $\begin{array}{ll}\text { Garameters } & \text { Groups } \\
\end{array}$ & $\begin{array}{l}\text { Carbetocin } \\
\text { group } \\
(\mathbf{n}=\mathbf{5 0})\end{array}$ & $\begin{array}{l}\text { Oxytocin } \\
\text { group } \\
(\mathbf{n}=\mathbf{5 0})\end{array}$ & P-value \\
\hline Hemoglobin drop changes $(\mathrm{mg} / \mathrm{dl})$ & $1.0 \pm 0.9$ & $2.1 \pm 1.1$ & 0.011 \\
\hline Bleeding volume $_{(\mathrm{mg} / \mathrm{dl})}$ & $421.19 \pm 110$ & $560.32 \pm 162$ & 0.008 \\
\hline Massage times (Seconds) & $3.26 \pm 0.7$ & $4.7 \pm 0.7$ & 0.001 \\
\hline Pulse Rate $_{(\text {No. })}$ & $87.23 \pm 6.4$ & $90.22 \pm 5.6$ & 0.015 \\
\hline Respiratory rate $_{(\mathrm{No} . / \mathrm{min})}$ & $17.91 \pm 1.9$ & $17.22 \pm 1.2$ & 0.032 \\
\hline Systolic Blood pressure $_{(\mathrm{mmHg})}$ & $109.11 \pm 8.2$ & $108.83 \pm 8.3$ & 0.866 \\
\hline
\end{tabular}

Regarding side effect, headache $(12 \%$ versus $4 \%$ ), dizziness ( $8 \%$ versus $2 \%$ ), and tremor $(10 \%$ versus $2 \%)$ occurred more frequent in oxytocin cases $(\mathrm{P}<$ $0.05)$; but nausea and vomiting were comparable in all cases $(\mathrm{P}>0.05)$. No cases of urinary retention were founded in all cases. Twenty percent in carbetocin cases and none of in oxytocin cases had pruritus $(\mathrm{P}<0.001)$ (Table 4).

Table (4): Comparison between casess as regard to side effects

\begin{tabular}{|l|c|c|c|}
\hline Groups & $\begin{array}{c}\text { Carbetocin group } \\
(\mathbf{n = 5 0})\end{array}$ & $\begin{array}{c}\text { Oxytocin group } \\
(\mathbf{n = 5 0})\end{array}$ & P-value \\
\hline Pomiting, $\mathrm{n}(\%)$ & $3(6 \%)$ & $4(8 \%)$ & 0.352 \\
\hline Headache, $\mathrm{n}(\%)$ & $2(4 \%)$ & $6(12 \%)$ & $\mathbf{0 . 0 0 1}$ \\
\hline Nausea, $\mathrm{n}(\%)$ & $6(12 \%)$ & $8(16 \%)$ & 0.265 \\
\hline Tremor, $\mathrm{n}(\%)$ & $1(2 \%)$ & $5(10 \%)$ & $\mathbf{0 . 0 0 6}$ \\
\hline Dizziness, $\mathrm{n}(\%)$ & $1(2 \%)$ & $4(8 \%)$ & $\mathbf{0 . 0 0 7}$ \\
\hline Pruritus, $\mathrm{n}(\%)$ & $10(20 \%)$ & $0(0 \%)$ & $<\mathbf{0 . 0 0 1}$ \\
\hline
\end{tabular}

\section{DISCUSSION}

Postpartum hemorrhage (PPH) is the primary reason of women death and morbidity. It accounts for about 1 quarter of all mother's deaths, and has incidence of about sex percent. PPH in many developed countries is estimated to have grown in prevalence and magnitude (Mehrabadi et al., 2013).

Our findings indicated that $60 \%$ and $40 \%$ of carbetocin and oxytocine, respectively, obtained extra uterotonic administration. The cases had mean intervals of oxytocin injection to misoprostol substantially greater than that of carbetocin. The mean time of the ICU stay in the oxytocin cases was also significantly higher.
However, El Behery et al. (2016) revealed that none in carbetocin cases versus $71.5 \%$ in oxytocin cases required extra uterotonics. Furthermore, Jin et al. (2016) reported that, in contrast to oxytocin in pregnant after C.S, carbetocin was associated with a significant decreased demand of extra uterotonic medications. Ibrahim et al. (2020) reported that $38 \%$ needed extra oxytocin, $8 \%$ in carbetocin cases, and $68 \%$ in oxytocin cases. This difference was significant. Patients in the oxytocin cases had 9 times the risk of needed other uterotonics as carbetocin cases. One of the four cases in carbetocin group was during $\mathrm{CS}$, and the other 3 patients received the extra oxytocin after delivery during the 
first 3 hours after operation. For the oxytocin cases, 13 patients needed the other oxytocin during the operation and 21 needed after delivery during the first 3 hours after operation. All patients had good uterine contraction thereafter until leaving the hospital.

In the study in our hands, the mean hemoglobin drop, blood loss, and massage times significantly raised in oxytocin cases comparing to carbetocin cases, while the blood pressure and respiratory rate were comparable between the two cases. Ibrahim et al. (2020) reported that the mean change in hemoglobin level 24 hours following $\mathrm{CS}$ in the carbetocin cases and in the oxytocin cases, the difference was significant. However, change in platelet count was not significantly different between both groups. Regarding Kansouh and El Naggar (2019), the difference between blood hemoglobin levels 24 hour postdelivery was not significantly lower in the carbetocin cases. Pregnant in oxytocin cases, $2 \mathrm{~h}$ after CS, showed a statistically significantly higher SBP and DBP than pregnant in carbetocin cases. However, Reyes and Gonzalez (2011), revealed that there were no differences between the carbetocin and oxytocin cases in hemoglobin concentration after delivery, or in rates of oliguria.

The present study showed that headache, dizziness, and tremor occurred more frequent in oxytocin cases, while nausea and vomiting were comparable in all cases. No cases of urinary retention were founded in all cases. Twenty percent in carbetocin cases and none of in oxytocin cases had pruritus. However, Jin et al. (2016) found that side effect was significantly reduced in the carbetocin cases.

Kansouh and El Naggar (2019), reported that there was no significant difference regarding incidence of nausea, vomiting, flushing, shivering, dyspnea, palpitations, and itching. The prevalence of tachycardia and headache was significantly raised in the carbetocin cases.

Nevertheless, use of meperidine as analgesics after delivery could be responsible for the nausea and vomiting recorded in the postnatal unit. Headache can also be associated with local anesthetic instead of a real uterotonic side effect. Abdominal pain can also be attributed not to the side effects of carbetocin or oxytocin, but to uterine contractions. It is kind of an indicator that the medication is successful in uterine tones and gains the intended goal. The protection and negative effects of carbetocin versus oxytocin after CS were measured in a recent report. The authors revealed that side effects were comparable between both cases, however, pain after delivery in carbetocin cases was significantly lower than in oxytocin cases and still significant from 1st to 3rd day after CS (De Bonis et al., 2012).

Another research showed that a single dose of carbetocin has comparable effect to a two-hour oxytocin infusion, which controls intra-operational blood loss following placental delivery (Larciprete et al., 2013).

\section{CONCLUSION}

Carbetocin tended to have the same efficacy and safety of oxytocin in PE, since it was easy to administer, needed a 
relatively small vehicle capability, and has a long-lasting uterotonic efficacy. So, it may have a better chance in severe PE.

\section{REFERENCES}

1. De Bonis M, Torricelli M, Leoni L, Berti P, Ciani V, Puzzutiello R, Severi FM, and Petraglia F. (2012): Carbetocin versus oxytocin after cesarean section: similar efficacy but reduced pain perception in women with high risk of postpartum hemorrhage. J Matern Fetal Neonatal Med, 25(6): 732-735.

2. El Behery, M. M., El Sayed, G. A., El Hameed, A. A. A., Soliman, B. S., Abdelsalam, W. A. and Bahaa, A. (2016): Carbetocin versus oxytocin for prevention of postpartum hemorrhage in obese nulliparous women undergoing emergency cesarean delivery. The Journal of Maternal-Fetal \& Neonatal Medicine, 29(8): 1257-1260.

3. Elbohoty AEH, Mohammed WE, Sweed M, Bahaa Eldin AM, Nabhan A, and AbdEI-Maeboud KHI. (2016): Randomized controlled trial comparing carbetocin, misoprostol, and oxytocin for the prevention of postpartum hemorrhage following an elective cesarean delivery. Int $\mathbf{J}$ Gynaecol Obstet, 134(3):324-328.

4. Fullerton, G., Danielian, P. J. and Bhattacharya, S. (2013): Outcomes of pregnancy following postpartum haemorrhage. BJOG: An International Journal of Obstetrics \& Gynaecology, 120(5): 621-627.

5. Ibrahim, Z. M., Sayed Ahmed, W. A., Abd El-Hamid, E. M., Taha, O. T. and Elbahie, A. M. (2020): Carbetocin versus oxytocin for prevention of postpartum hemorrhage in hypertensive women undergoing elective cesarean section. Hypertension in Pregnancy, 39(3): 319-325.

6. Jin, B., Du, Y., Zhang, F., Zhang, K., Wang, L. and Cui, L. (2016): Carbetocin for the prevention of postpartum hemorrhage: a systematic review and meta-analysis of randomized controlled trials. The Journal of Maternal-Fetal \& Neonatal Medicine, 29(3): 400-407.

7. Kansouh, A. M. and El Naggar, M. A. (2019): Carbetocin versus oxytocin in prevention of postpartum hemorrhage in late preterm twin pregnancy following cesarean section: a prospective clinical study. Journal of Medicine in Scientific Research, 2(1): 5458.

8. Larciprete, G., Montagnoli, C., Frigo, M., Panetta, V., Todde, C., Zuppani, B. Centozone C., Bompiani A., Malandrenis L., Cirese A. and Valensise H. (2013): Carbetocin versus oxytocin in caesarean section with high risk of post-partum haemorrhage. Journal of Prenatal Medicine, 7(1): 12-17.

9. Mehrabadi A, Hutcheon J, Lee L, Kramer M, Liston $R$ and Joseph K. (2013): Epidemiological investigation of a temporal increase in atonic postpartum hemorrhage: a population-based retrospective cohort study. BJOG, 120:853-858.

10. Reyes, O. A. and Gonzalez, G. M. (2011): Carbetocin versus oxytocin for prevention of postpartum hemorrhage in patients with severe preeclampsia: a double-blind randomized controlled trial. Journal of Obstetrics and Gynaecology Canada, 33(11): 1099-1104. 


\section{عقار الكاربيتوسين في منع نزيف ما بعد الو لادة القيصرية}

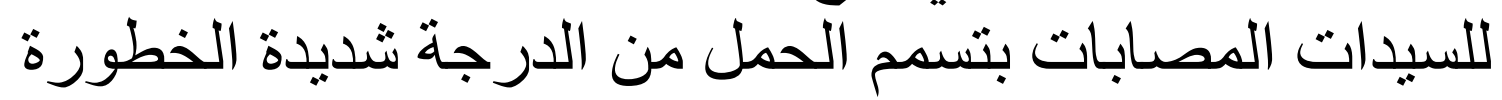
مقارنة بعقار الاوكسيتوسين

احمد سعد الدين محمد، مفيد فوزي محمد، أحمد محمد الصادق

قسم أمراض النساء والتوليد، كليه الطب بنين القاهره، جامعه الأزهر

E-mail: drahmedsaad1989@yahoo.com

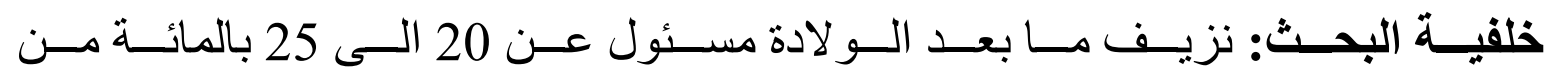

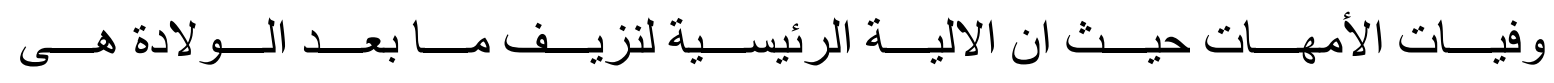

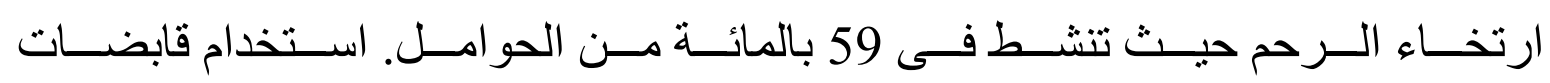
الرحم بعد الو لادة حيوى فى تجنب حدوثه.

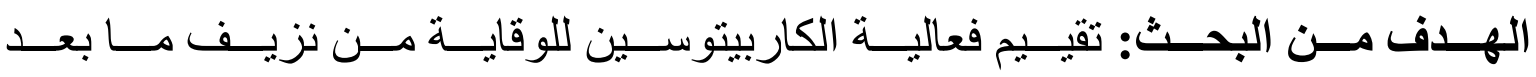

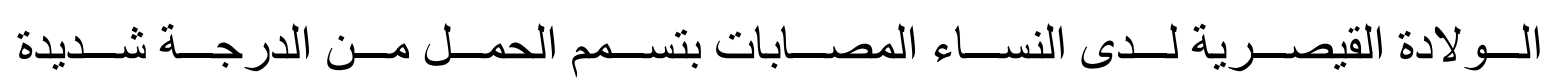
الخطورة مقارنة بالأوكسيتوسين.

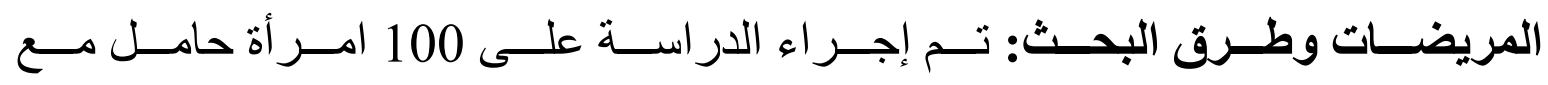

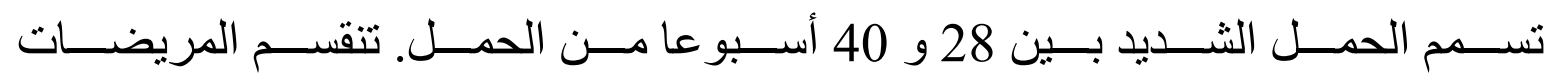

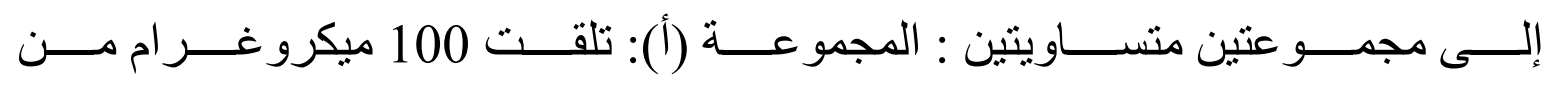

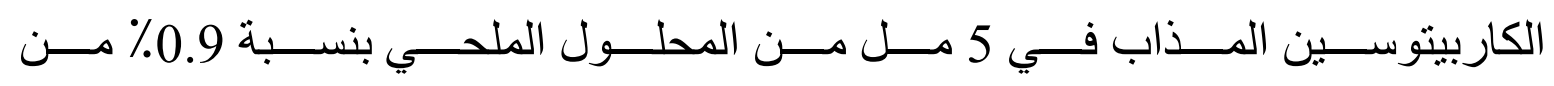

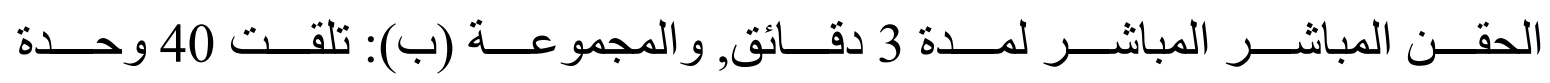

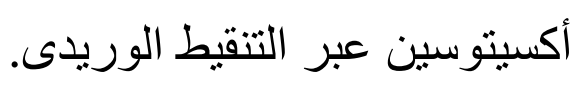

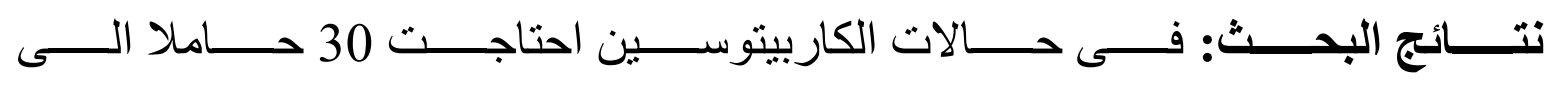

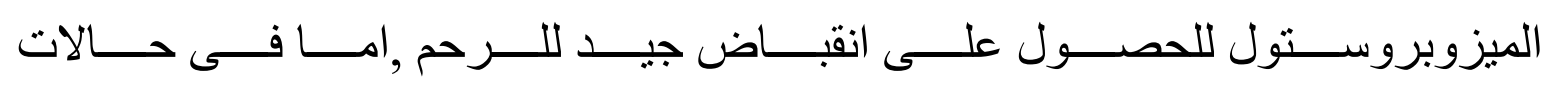

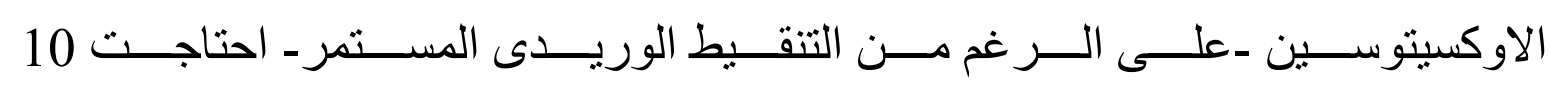

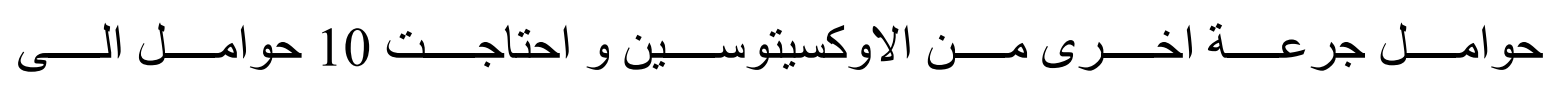


الميزوبروســـتول. كمــــا ان اســـتخدام الجر عـــات الز ائـــدة مـــن قابضــــات الـــرحم

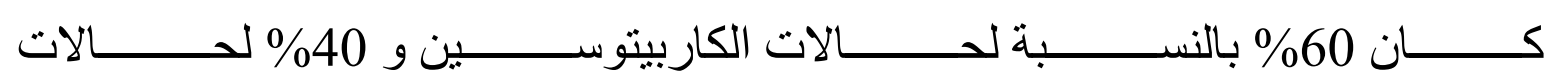
الاوكسيتوسين.

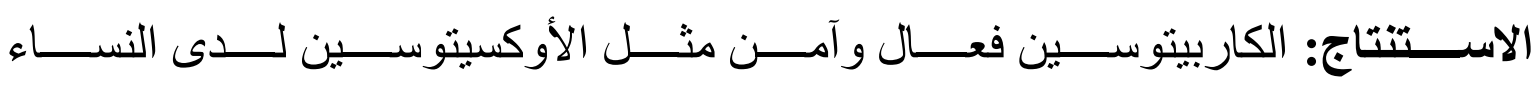

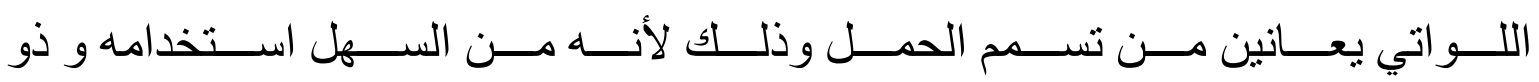

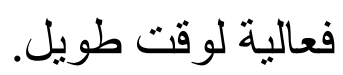

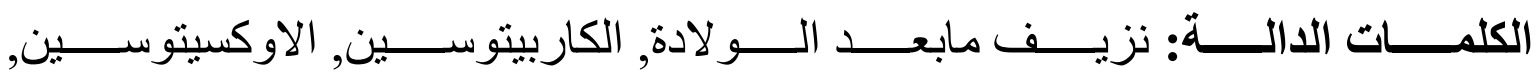

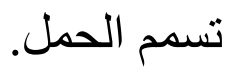

